\title{
Evaluasi Morfologi, Produksi dan Kualitas Tumbuhan Asystasia gangetica (L.) T. Anderson pada Lingkungan yang Berbeda
}

\author{
Evaluation of Asystasia gangetica (I.) T. Anderson Morphology, Production and Quality on Different Environment \\ Condition \\ N R Kumalasari*, R I Putra, L Abdullah
}

Corresponding email:

nurku@apps.ipb.ac.id

Departemen Ilmu Nutrisi dan Teknologi Pakan, Fakultas Peternakan, Institut Pertanian Bogor (Bogor Agricultural University/IPB University)

\section{ABSTRACT}

Ara Sungsang (Asystasia gangetica (L.) T. Anderson) is a perennial creeper that grows rapidly and widely in various regions. The aim of this study was to evaluate the effect of different environmental condition on plant morphology, biomass production and forage quality. This research was conducted from August 2017 to March 2018 in Purwakarta, Sumedang, Lebak and Bogor. Plant morphological samples were observed in 10 different plants, while biomass production was taken at 4 sampling points in each region using the $0.5 \mathrm{~m} \times 0.5 \mathrm{~m}$ quadrant. The variables measured were plant length, the length, width and number of leaves; branches number, fresh and dry weight of plant; and plant nutrient content. The data obtained were analyzed by ANOVA Matrix Unbalance by software R-3.3.2., then the significantly different variables were further tested by the Duncan test. The results showed that ara sungsang length was $41-250 \mathrm{~cm}$, branches number was 9-38, leaves number was 39-100, 3-5 cm and 7-13 cm of leaf width and length respectively. The results of the forage quality showed that the nutrient content of the breech figs (Ara Sungsang) were as follows dry matter $19.84 \%$ $-26.87 \%$, crude protein $10.90 \%-35.17 \%$, crude fat $0.78 \%-4.71 \%$, crude fiber $10.22 \%$ $48.97 \%$ and nitrogen free extract 31.99\%-54.21\%. It was concluded that $A$. gangetica morphology, biomass production and forage quality were strongly affected by environmental condition.

Key words: Asytasia gangetica (L.) T. Anderson, biomass production, environment, morphology, nutrient content

\section{ABSTRAK}

Ara Sungsang (Asystasia gangetica (L.) T. Anderson) adalah tanaman yang tumbuh dengan cepat dan dapat ditemukan di berbagai wilayah. Penelitian ini bertujuan untuk mengevaluasi morfologi, produksi biomassa dan kualitas tumbuhan sebagai hijauan. Penelitian ini dilakukan pada bulan Agustus 2017- Maret 2018 di Kabupaten Purwakarta, Sumedang, Lebak dan Bogor. Sampel morfologi tumbuhan diamati pada 10 tumbuhan yang berbeda sedangkan produksi diambil pada 4 titik sampling di setiap wilayah menggunakan kuadran 0,5m x 0,5 m. Variabel yang diukur adalah panjang tajuk, panjang daun, lebar daun, jumlah daun, jumlah ranting, bobot segar dan berat kering tanaman dan kandungan nutrien. Analisis statistik menggunakan Analysis of Variance (ANOVA) Matrix Unbalance dengan software R-3.3.2., peubah yang berbeda diuji lagi dengan uji Duncan. Tumbuhan ara sungsang memiliki panjang tajuk $41 \mathrm{~cm}$ $250 \mathrm{~cm}$, jumlah ranting 9-38, jumlah daun adalah 39-100, lebar daun adalah $3 \mathrm{~cm}-5 \mathrm{~cm}$ dan panjang daun $7 \mathrm{~cm}-13 \mathrm{~cm}$. Hasil analisis kualitas hijauan menunjukkan bahwa kandungan nutrien ara sungsang berupa protein kasar 10,90\%-35,17\%; lemak kasar 0,78\%-4,71\%; serat kasar 10,22\%-48,97\% dan bahan ekstrak tanpa nitrogen 31,99\%$54,21 \%$. Kesimpulan penelitian bahwa morfologi, produksi dan kualitas tumbuhan $A$. gangetica sangat dipengaruhi oleh keadaan lingkungan.

Kata kunci: Asytasia gangetica (L.) T. Anderson, kandungan nutrien, lingkungan, morfologi, produksi biomassa 


\section{PENDAHULUAN}

Asystasia gangetica (L.) T. Anderson yang sering disebut sebagai ara sungsang, rumput israel dan china violet, merupakan salah satu tanaman yang tumbuh secara merambat dengan cepat dan dapat ditemukan di daerah tropis. A.gangetica berasal dari genus Asystasia Blume Asystasia dengan famili Acanthaceae - acanthus family (Tilloo et al. 2012).

A. gangetica banyak ditemukan di berbagai wilayah di Jawa Barat, terutama di Bogor, Banten dan Garut (Kumalasari et al. 2020a). A. gangetica telah digunakan di berbagai wilayah sebagai pakan ternak, seperti Riau (Ramdani et al. 2017), Batanghari (Adriadi et al. 2012) termasuk di wilayah Asia (Norlindawati et al. 2019) dan Afrika (Adigun et al. 2014). Menurut Kumalasari et al. (2020b), A. gangetica memiliki kandungan nutrien yang baik sebagai pakan ternak, terutama daunnya dengan kandungan protein kasar mencapai $24,2 \%$.

A. gangetica dapat tumbuh pada berbagai wilayah dengan kondisi yang beragam. Pada daerah yang ternaungi seperti daerah perkebunan dengan tanaman yang relatif tinggi, tanaman ini dapat menghasilkan daun dan menghasilkan organ vegetatif sehingga memiliki pertumbuhan yang cepat dan kompetitif serta sering kali digunakan sebagai pakan ternak ruminansia (Junaidi \& Sawen 2010). Daun A. gangetica memiliki kandungan nutrien yang lebih tinggi dibandingkan bagian batang (Kumalasari et al. 2020b), oleh karena itu penting dilakukan penelitian mengenai keragaman morfologi tumbuhan $A$. gengetica di berbagai wilayah untuk mengetahui produktivitas dan kualitas $A$. gangetica pada lingkungan yang berbeda.

Tujuan dari penelitian ini adalah untuk mengevaluasi keragaman morfologi, potensi produksi biomassa dan kualitas tumbuhan A. gangetica sebagai hijauan pakan di beberapa wilayah Jawa Barat dan Banten.

\section{METODE}

\section{Observasi}

Penelitian ini dilakukan observasi di Desa Mekarjaya, Kecamatan Kiara Pedes, Kabupaten Purwakarta; Desa Hariang, Kecamatan Buah Dua, Kabupaten Sumedang; Desa Babakan, Kecamatan Dramaga, Kabupaten Bogor serta Desa Kanekes, Kecamatan Leuwidamar Kabupaten Lebak, Banten.

\section{Pengambilan sampel}

Pada setiap wilayah ditetapkan 3 (tiga) titik sampling dimana tumbuhan ara sungsang ditemukan tumbuh. Penetapan titik sampling hijauan dilakukan dengan cara membagi lahan secara acak menurut kelompok tumbuhnya, karena tumbuhan ara sungsang hidup secara berkelompok. Pengambilan sampel hijauan dilakukan dengan menggunakan kuadran 0,5 $\mathrm{m}$ x 0,5 m pada masing-masing titik terpilih. Hijauan dalam kuadran di potong $3 \mathrm{~cm}$ sampai $5 \mathrm{~cm}$ dari permukaan tanah (Junaidi \& Sawen 2010). Hijauan dimasukan ke dalam amplop kemudian ditimbang berat segar totalnya. Hasil penimbangan berat segar dicatat pada formulir pengambilan sampel.

\section{Variabel penelitian}

Panjang tajuk, dilakukan dengan mengukur tumbuhan dari pangkal batang sampai pada bagian yang tertinggi dari tanaman tersebut yaitu keseluruhan bagian tumbuhan yang berada di atas permukaan tanah yang menempel pada batang utama sampai dengan ujung daun.

Panjang daun, dilakukan dengan mengukur panjang dari pangkal daun sampai ujung daun.

Lebar daun, dilakukan dengan mengukur sisi samping daun yang paling lebar.

Jumlah daun, dilakukan dengan menghitung jumlah daun pada seluruh bagian tumbuhan yang berada diatas permukaan tanah mulai dari daun yang paling bawah sampai daun yang paling atas dalam satuan helai.

Jumlah cabang, dilakukan dengan cara mengitung jumlah percabangan pada seluruh bagian tumbuhan yang berada diatas permukaan tanah mulai dari cabang yang paling bawah sampai yang paling atas.

Berat segar tumbuhan, dilakukan dengan cara menimbang berat tumbuhan dalam satu kuadran. Pada fase vegetatif, biomassa yang akan ditimbang adalah bobot tumbuhan secara keseluruan yang meliputi akar, batang dan daun. Berat segar tumbuhan dinyatakan dalam satuan g per $\mathrm{m}^{2}$.

Bobot kering tumbuhan (batang dan daun), dengan menimbang biomassa tumbuhan sebelum dikeringkan. Pengeringan dilakukan dengan menggunakan oven pada suhu $60^{\circ} \mathrm{C}$ selama $2 \times 24$ jam per sampel. Kemudian ditimbang dengan menggunakan timbangan digital dengan satuan g per $\mathrm{m}^{2}$.

Luas permukaan daun ( $\left.\mathrm{cm}^{2}\right)$, sampel daun diambil secara acak dengan mempertimbangkan aspek letak/posisi daun yang terdiri dari tajuk bagian atas (pucuk), bagian tengah dan bagian bawah (strata) sebanyak 50 daun. Kemudian diukur luas daunnya dan dijumlahkan hingga mendapatkan luas permukaan total daun dengan menggunakan software image-J.

\section{Analisis Nutrien}

Analisis proksimat (AOAC 2005) yang dilakukan adalah kadar air (KA), protein kasar (PK), serat kasar (SK), lemak kasar (LK), dan abu.

\section{Analisis Data}

Analisis data dilakukan dengan uji ragam ANOVA Matrix Unbalance dengan software R-3.3.2., jika terdapat faktor yang berbeda nyata maka diuji dengan uji Duncan. 


\section{HASIL DAN PEMBAHASAN}

\section{Kondisi Umum}

Pengambilan sampel Asystasia gangetica dilakukan di empat wilayah kabupaten di Jawa Barat dan Banten yaitu di Desa Mekarjaya, Kecamatan Kiara Pedes, Kabupaten Purwakarta; Desa Babakan, Kecamatan Dramaga, Kabupaten Bogor; Desa Hariang, Kecamatan Buah Dua, Kabupaten Sumedang dan Desa Kanekes, Kecamatan Leuwidamar, Kabupaten Lebak, Banten. Di wilayah pengambilan sampel memiliki kondisi cuaca dan iklim rata-rata tahunan yang dapat dilihat pada Tabel 1.

Suhu rata-rata tahunan di Kabupaten Purwakarta dan Sumedang lebih tinggi dibandingkan Bogor dan Lebak, kondisi ini dapat dilihat terkait dengan lama penyinaran yang lebih pendek. Berbeda dengan pola kelembaban udara yang lebih tinggi di Kabupaten Purwakarta dan Bogor sedangkan di Sumedang dan Lebak kondisi lingkungan lebih kering.

\section{Keragaman Morfologi Asystasia gangetica (L.) T. Anderson pada Lingkungan yang Berbeda}

Keragaman lingkungan pengambilan sampel A. gangetica dalam penelitian berupa perbedaan lokasi kota dan kondisi tempat pengambilan sampel. Pengambilan sampel di desa Cikabayan, Babakan, Dramaga Kabupaten Bogor berada dalam areal perkebunan kelapa sawit dengan tingkat naungan rata-rata $80 \%$. Pengambilan sampel di Kabupaten Purwakarta berada di perkebunan singkong dan pisang. Tingkat naungan di bawah pohon singkong memiliki tingkat naungan rata-rata 30\% dan dibawah naungan pohon pisang dengan tingkat naungan rata-rata 35\%. Pengambilan sampel di Sumedang di tepi jalan dengan naungan pohon albasia dan pohon jati dengan tingkat naungan rata-rata yaitu sebesar $75 \%$. Pengambilan sampel penelitian di Lebak di bawah naungan pohon albasia dan pohon pisang. Tingkat naungan di bawah pohon pisang diperkiraan memiliki tingkat naungan rata-rata $35 \%$ sedangkan di bawah naungan pohon albasia memiliki tingkat naungan ratanaungan memiliki peran dalam proses fisiologis seperti pertumbuhan dan perkembangan, sehingga semakin rendah tingkat naungan maka cahaya matahari akan lebih banyak membantu dalam proses pertumbuhan.

Tabel 1 Kondisi cuaca dan iklim rata-rata tahunan di berbagai wilayah pengambilan sampel

Sumber: BPS Kabupaten Sumedang, Lebak dan Purwakarta (2015) dan Kabupaten Bogor (2017) rata sebesar 50\%. Menurut Haryanti (2010), tingkat

\begin{tabular}{lccccc}
\hline Kabupaten & $\begin{array}{c}\text { Suhu } \\
\left({ }^{\circ} \mathrm{C}\right)\end{array}$ & $\begin{array}{c}\text { Kelembaban } \\
(\%)\end{array}$ & $\begin{array}{c}\text { Curah } \\
\text { hujan } \\
(\mathrm{mm})\end{array}$ & $\begin{array}{c}\text { Lama } \\
\text { Penyinaran } \\
\text { Matahari } \\
(\text { jam/hari) }\end{array}$ & $\begin{array}{c}\text { Jenis } \\
\text { Tanah }\end{array}$ \\
\hline Purwakarta & 25,6 & 91 & 2712 & 9 & Latosol \\
Sumedang & 26,2 & 85 & 3025 & 9 & Latosol \\
Bogor & 23,3 & 93,6 & 4100 & 7 & Latosol \\
Lebak & 23,8 & 80 & 3000 & 8 & Podsolik \\
\hline Sumber:
\end{tabular}

Tabel 2 Keragaman morfologi Asystasia gangetica

\begin{tabular}{|c|c|c|c|c|c|c|}
\hline $\begin{array}{l}\text { Jenis } \\
\text { Naungan }\end{array}$ & $\begin{array}{c}\text { Naungan } \\
(\%)\end{array}$ & $\begin{array}{c}\text { Panjang } \\
\text { Tajuk } \\
(\mathrm{cm})\end{array}$ & $\begin{array}{l}\text { Jumlah } \\
\text { Cabang }\end{array}$ & $\begin{array}{l}\text { Jumlah } \\
\text { Daun }\end{array}$ & $\begin{array}{l}\text { Lebar } \\
\text { Daun } \\
(\mathrm{cm})\end{array}$ & $\begin{array}{c}\text { Panjang } \\
\text { Daun } \\
(\mathrm{cm})\end{array}$ \\
\hline Singkong & 30 & $250 \pm 39,21^{a}$ & $38 \pm 3,69^{a} 1$ & $100 \pm 11,59^{a}$ & $3 \pm 1,04^{c}$ & $7 \pm 1,26^{c}$ \\
\hline Pisang & 35 & $119 \pm 41,63^{b}$ & $36 \pm 11,42^{\mathrm{a}}$ & $42 \pm 22,82^{b}$ & $3 \pm 0,40^{c}$ & $8 \pm 0,99^{c}$ \\
\hline Albasia & 50 & $97 \pm 35,33^{\mathrm{bc}}$ & $30 \pm 14,90^{\mathrm{a}}$ & $71 \pm 26,67^{\mathrm{ab}}$ & $4 \pm 1,18^{b}$ & $10 \pm 3,04^{b}$ \\
\hline $\begin{array}{l}\text { Albasia } \\
\text { dan Jati }\end{array}$ & 75 & $71 \pm 18,15^{\mathrm{bc}}$ & $27 \pm 12,50^{\mathrm{ab}}$ & $39 \pm 37,51^{b}$ & $3 \pm 0,58^{c}$ & $7 \pm 0,76^{c}$ \\
\hline Sawit & 80 & $41 \pm 6,16^{c}$ & $9 \pm 1,84^{b}$ & $47 \pm 14,30^{b}$ & $5 \pm 0,43^{a}$ & $13 \pm 1,55^{a}$ \\
\hline
\end{tabular}

Superskrip yang berbeda pada kolom yang sama menunjukkan perbedaan yang nyata $(\mathrm{p}<0,05)$

Jenis naungan mempengaruhi morfologi tumbuhan $A$. gangetica, yaitu pada panjang tajuk, jumlah cabang, jumlah, lebar dan panjang daun (Tabel 2). Panjang tajuk tumbuhan mewakili panjang batang dan ditambah sebagian daun yang dipucuk. Panjang tajuk, jumlah cabang dan jumlah daun lebih besar pada kondisi cahaya matahari yang lebih tinggi (naungan 30\%). Pada lingkungan yang lebih ternaungi tumbuhan $A$. gangetica mengurangi jumlah daun untuk mengimbangi jumlah cahaya yang terbatas (Anggraeni, 2010).

Hasil ini berbanding terbalik dengan panjang dan lebar daun tumbuhan A. gangetica yang semakin lebar dan panjang daun pada kondisi yang lebih ternaungi. Pada Tabel 2 tampak lebar dan panjang daun yang berada dibawah naungan $30 \%$ hanya memiliki lebar 3 $\pm 1,04 \mathrm{~cm}$ dan panjang $7 \pm 1,26 \mathrm{~cm}$ sedangkan lebar dan panjang daun yang berada dibawah naungan pohon sawit dengan tingkat naungan tertinggi yaitu $80 \%$ memiliki lebar $5 \pm 0,43 \mathrm{~cm}$ dan panjang $13 \pm 1,55 \mathrm{~cm}$. Nilai lebar dan panjang daun tersebut masih sesuai dengan hasil penelitian Amstrong (2002) dan Grubben (2004) yang menyatakan bahwa lebar dan panjang daun tumbuhan $A$. gangetica memiliki lebar $2 \mathrm{~cm}-5 \mathrm{~cm}$ dan panjang $4 \mathrm{~cm}-9 \mathrm{~cm}$.

Nilai luas permukaan daun tumbuhan $A$ gangetica memiliki luas permukaan daun lebih besar pada bagian bawah strata tumbuhan, sedangkan pada bagian strata atas tumbuhan memiliki luas permukaan lebih kecil (Tabel 3). Luas permukaan daun yang berasal dari bawah naungan pohon singkong dengan tingkat naungan 30\% memiliki nilai $4,99 \mathrm{~cm}^{2}$ pada bagian strata atas tumbuhan, sedangkan bagian strata tengah tumbuhan memiliki nilai $8,61 \mathrm{~cm}^{2}$ dan $10,04 \mathrm{~cm}^{2}$ pada daun bagian strata bawah tumbuhan. Nilai luas daun total yang berasal dari bawah naungan pohon pisang yang memiliki tingkat naungan 35\% memiliki nilai luas permukaan

Tabel 3 Rataan luas permukaan daun Asystasia gangetica $\left(\mathrm{cm}^{2}\right)$

\begin{tabular}{lcccc}
\hline \multirow{2}{*}{$\begin{array}{l}\text { Jenis } \\
\text { naungan }\end{array}$} & Naungan (\%) & \multicolumn{3}{c}{$\begin{array}{l}\text { Rata-rata Luas Permukaan } \\
\text { Daun }\left(\mathrm{cm}^{2} \text { daun }\right.\end{array}$}
\end{tabular}


daun pada bagian strata atas, tengah dan bawah tumbuhan memiliki nilai masing-masing 5,25 $\mathrm{cm}^{2} ; 8,96$ $\mathrm{cm}^{2}$ dan $11,44 \mathrm{~cm}^{2}$, sedangkan luas daun total yang berasal dari bawah naungan pohon albasia memiliki nilai luas daun total masing-masing $5,70 \mathrm{~cm}^{2} ; 9,14 \mathrm{~cm}^{2}$ dan $10,67 \mathrm{~cm}^{2}$ pada bagian strata atas, tengah dan bawah tumbuhan. Luas permukaan daun yang berasal dari bawah naungan albasia dan jati memiliki luas permukaan $6,27 \mathrm{~cm}^{2} ; 8,84 \mathrm{~cm}^{2}$ dan $11,38 \mathrm{~cm}^{2}$ serta luas permukaan daun yang berasal dari bawah naungan pohon sawit yang memiliki tingkat naungan $80 \%$ masing-masing $7,82 \mathrm{~cm}^{2}$; $9,27 \mathrm{~cm}^{2}$ dan $16,46 \mathrm{~cm}^{2}$ pada bagian strata atas, tengah dan bawah tumbuhan.

Daun yang berada pada bagian strata bawah tumbuhan biasanya memiliki luas permukaan lebih besar, kemudian berukuran lebih kecil pada bagian atas strata tumbuhan (Laksono \& Damayanti 2005). Haryanti (2010) melaporkan bahwa tanaman yang mempunyai luas permukaan daun yang lebih besar akan menambah kemampuan tanaman untuk berfotosintesis lebih optimal, hal ini karena lebih luasnya permukaan daun tanaman menerima cahaya matahari sebagai sumber energi utama dalam proses fotosintesis.

\section{Potensi Produksi Hijauan A. gangetica pada Wilayah yang Berbeda}

Produksi biomassa tumbuhan A. gangetica berdasarkan berat kering yang berasal dari Bogor memiliki nilai yang tinggi yaitu $71,22 \pm 45,91 \mathrm{~g} \mathrm{~m}^{-2}$ sedangkan produksi biomassa di Kabupaten Sumedang memiliki nilai yang paling rendah yaitu 33,13 $\pm 11,98 \mathrm{~g} \mathrm{~m}^{-2}$. Produksi biomassa berat kering di Kabupaten Purwakarta dan Kabupaten Lebak masing-masing memiliki nilai

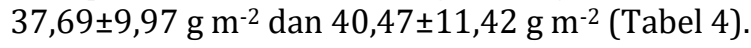

Proporsi batang dan daun A. gangetica menunjukan bahwa proporsi batang lebih tinggi dibandingkan dengan proporsi daun. Rata-rata produksi batang yang dihasilkan yaitu $57,70 \%$ sedangkan rata-rata produksi daun yaitu menghasilkan 42,37\%. Presentase batang yang lebih banyak dapat mempengaruhi terhadap kandungan serat kasar dan komponen nutrien lain dalam tumbuhan. Selain itu, presentase daun sangat berpengaruh terhadap kadar protein kasar karena memiliki zat hijau daun (klorofil) yang memiliki komponen utama nitrogen (Silungwe 2011). Tingginya proporsi batang dibandingkan daun dapat menurunkan kualitas hijauan pakan karena kandungan protein yang kecil dan serat kasar pada batang yang lebih besar.

Tabel 4 Produksi biomassa Asystasia gangetica

\begin{tabular}{|c|c|c|c|c|}
\hline Asal & $\begin{array}{l}\text { Proporsi } \\
\text { Batang (\%) }\end{array}$ & $\begin{array}{l}\text { Proporsi } \\
\text { Daun (\%) }\end{array}$ & $\begin{array}{c}\text { Berat } \\
\text { Kering } \\
\left({\left.\text { g per } \mathrm{m}^{2}\right)}\right.\end{array}$ & $\begin{array}{c}\text { Berat Segar } \\
\left(\mathrm{g} \text { per } \mathrm{m}^{2}\right)\end{array}$ \\
\hline Purwakarta & $55,18 \pm 3,56$ & $44,82 \pm 3,56$ & $37,69 \pm 9,97^{b}$ & $190 \pm 100,53^{b}$ \\
\hline Sumedang & $61,41 \pm 2,53$ & $38,59 \pm 2,53$ & $33,13 \pm 11,98^{b}$ & $167 \pm 104,08^{b}$ \\
\hline Lebak & $58,26 \pm 5,05$ & $41,74 \pm 5,05$ & $40,47 \pm 11,42^{a b}$ & $204 \pm 78,28^{\mathrm{ab}}$ \\
\hline Bogor & $55,67 \pm 3,32$ & $44,33 \pm 3,32$ & $71,22 \pm 45,91^{a}$ & $359 \pm 164,08^{a}$ \\
\hline
\end{tabular}

Tabel 5 Komposisi nutrien Asystasia gangetica (100\% BK)

\begin{tabular}{|c|c|c|c|c|c|c|c|}
\hline \multirow{2}{*}{ Asal } & \multirow{2}{*}{ Bagian } & \multirow{2}{*}{ KA } & \multicolumn{5}{|c|}{ Nutrien (\% BK) } \\
\hline & & & Abu & LK & PK & SK & BETN \\
\hline Sumedanga & Batang+Daun & 80,16 & 12,05 & 1,65 & 10,90 & 21,20 & 54,21 \\
\hline Purwakarta ${ }^{a}$ & Batang+Daun & 79,45 & 15,92 & 0,78 & 12,58 & 18,06 & 52,66 \\
\hline Lebak $^{b}$ & Daun & 78,07 & 13,14 & 4,71 & 23,71 & 21,59 & 36,84 \\
\hline Bogor & Daun & 75,23 & 14,38 & 2,18 & 35,17 & 10,22 & 38,04 \\
\hline Bogorb & Batang & 73,37 & 10,70 & 2,32 & 6,02 & 48,97 & 31,99 \\
\hline $\begin{array}{l}\text { BK dalam } 1 \\
\text { Purwakarta d } \\
\text { Bogor analisis } \\
\text { Pusat Penel }\end{array}$ & $\begin{array}{l}\text { 0\%. Sumedang } \\
\text { engan komposit } \\
\text { daun; Bogor an } \\
\text { itian Sumberd }\end{array}$ & $\begin{array}{l}\text { denga } \\
\text { daun d } \\
\text { alisis ba } \\
\text { laya H }\end{array}$ & $\begin{array}{l}\text { an kom } \\
\text { dan bata } \\
\text { atang. }{ }^{a} \\
\text { layati }\end{array}$ & $\begin{array}{l}\text { lasil an } \\
\text { dan }\end{array}$ & $\begin{array}{l}\text { daun c } \\
\text { ebak an } \\
\text { halisis La } \\
\text { Biotekn }\end{array}$ & nologi & $\begin{array}{l}\text { atang; } \\
\text { daun; } \\
\text { orium } \\
\text { IPB. }\end{array}$ \\
\hline
\end{tabular}

\section{Kualitas Hijauan A. gangetica pada Wilayah yang Berbeda}

Hasil analisis nutrien tumbuhan A. gangetica pada masing-masing bagian daun, batang maupun campuran keduanya dapat dilihat pada Tabel 4. Kadar air (KA) yang terdapat pada bagian campuran batang dan daun memiliki nilai antara 73,37\% - 80,16\%, protein kasar (PK) berkisar 6,02\% - 35,17\%, lemak kasar (LK) 0,78\% $4,71 \%$, serat kasar (SK) 10,22\% - 48,97\% dan BETN $31,99 \%$ - 54,21\%. Hasil analisis kandungan nutrient menunjukkan bahwa $A$. gangetica memiliki potensi untuk dimanfaatkan sebagai pakan ternak, terutama bagian daun.

Tingginya keragaman kandungan nutrien $A$. gangetica pada penelitian ini karena analisis nutrien dilakukan pada komponen tumbuhan yang beragam. Analisis nutrien daun saja menunjukkan kandungan protein yang tinggi $(23,71 \%-35,17 \%)$ sedangkan kandungan protein batang hanya $6.02 \%$. Hal ini sesuai dengan hasil penelitian Kumalasari (2020b) yang menyebutkan bahwa setiap bagian tumbuhan memiliki kualitas nutrien yang berbeda.

\section{SIMPULAN}

Morfologi tumbuhan $A$. gangetica sangat dipengaruhi oleh keadaan lingkungan, terutama naungan yang dipengaruhi oleh tumbuhan tinggi di sekitarnya. $A$. gangetica yang mendapatkan sedikit naungan (30\%) dapat memiliki panjang batang, jumlah cabang dan daun yang lebih banyak dibandingkan pada naungan yang lebih gelap. Panjang, lebar dan luas daun A. gangetica lebih besar pada naungan yang lebih gelap. Produksi dan kualitas hijauan A. gangetica tertinggi di daerah Bogor dengan kadar air yang lebih rendah dibandingkan daerah lain. Bagian daun tumbuhan A. gangetica memiliki kualitas nutrien yang lebih baik dibandingkan batang baik untuk diberikan pada ternak. 


\section{DAFTAR PUSTAKA}

Adriadi A, Chairul \& Solfiyeni. 2012. Analisis vegetasi gulma pada perkebunan kelapa sawit (Elais quineensis Jacq.) di Kilangan, Muaro Bulian, Batang Hari. Jurnal Biologi Universitas Andalas. 1(2): 108115

Adigun OS, Okeke EN, Makinde OJ \& Umunna MO. 2014. Effect of replacing wheat offal with Asystasia gangetica Leaf Meal (ALM) on growth performance and haematological parameters of weaner rabbits. Greener Journal of Agricultural Sciences. 4 (1): 009-014

Amstrong EM. 2002. Type of Leafs. [diakses 10 Maret2018]. Tersedia pada: http://www2.palomar.edu/users/warmstrong/termlf2.htm

Anggraeni, B.W. 2010. Studi morfo-anatomi dan pertumbuhan kedelai (Glycine $\max (\mathrm{L}$.$) Merr.) pada kondisi cekaman intensitas cahaya$ rendah. Skripsi. Bogor (ID) :Fakultas Pertanian IPB

Grubben JH. 2004. Vegetables. PROTA (Plant Resources of Tropical Africa) Foundation. Wageningen (NL): PROTA

Haryanti S. 2010. Pengaruh naungan yang berbeda terhadap jumlah stomata dan ukuran porus stomata daun Zephyranthes Rosea Lind. Buletin Anatomi dan Fisiologi. 18(1):41-48

Junaidi M \& Sawen D. 2010. Keragaman botanis dan kapasitas tampung padang penggembalan alami di Kabupaten Yapen. Jurnal Ilmu Peternakan. 5 (2): 92-97.

Kumalasari, NR, Sunardi, Khotijah L \& Abdullah L. 2020a. Evaluasi potensi produksi dan kualitas tumbuhan penutup tanah sebagai hijauan pakan di bawah naungan perkebunan di Jawa Barat. Jurnal Ilmu Nutrisi Dan Teknologi Pakan. 18(1): 7-10.

Kumalasari NR, Abdullah L, Khotijah L, Wahyuni L, Indriyani, Ilman N \& Janato F. 2020b. Evaluation of Asystasia gangetica as a potential forage in terms of growth, yield and nutrient concentration at different harvest ages. Tropical Grasslands-ForrajesTropicales. 8 (2): $153-157$

Norlindawati AP, Haryani H, Sabariah B, Mohamad NI, Samijah A, Mohd SJ \& Zul EW. 2019. Chemical composition of weeds as potential forage in integrated farming. Malaysian Journal of Veterinary Research. 10(2): 19-24

Laksono BA \& Damayanti A 2015. Analisys of the sufficiency of angsana trees (Pterocarpus indicus) in absorbing carbon monoxide (CO) due to motor vehicles activity on the Ahmad Yani street Surabaya. Journal of Applied and Natural Sciences. 7(2): 2-7.

Ramdani D, Abdullah L \& Kumalasari NR. 2017. Analisis potensi hijauan lokal pada sistem integrasi sawit dengan ternak ruminansia di Kecamatan Mandau Kabupaten Bengkalis Provinsi Riau. Buletin Makanan Ternak. 104 (1): 1-8

Silungwe D. 2011. Evaluation of forage yield and quality of sorghum, sudangrass and pearl millet cultivars in manawatu. [tesis] Palmerston North (NZ): Massey University.

Tilloo SK, Pande VB, RasalaTM, \& Kale VV. 2012. Asystasia gangetica Review on multipotential application. International Research Journal of Pharmacy. 3 (4): 18-20 